\title{
Psoriasis - the Impact on an Individual's Mental State and Quality Of Life
}

1 Šárka Vévodová

2 Filip Havelka

1 Jiří Vévoda

1 Bronislava Grygová

1 Department of Humanities and Social Sciences, Faculty of Health Sciences

Palacký University Olomouc, Czech Republic

2 University Hospital Olomouc, Czech Republic

\begin{abstract}

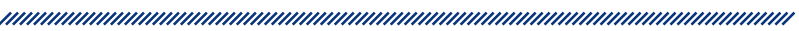

Introduction: Psoriasis is a chronic skin disease characterized by scaly patches affecting approximately $2-5 \%$ of the population. The disease has a negative impact on quality of life and, therefore, psoriatic patients often develop depression. Our work deals with quality of life and depression in psoriasis sufferrers and strives to determine the correlation between their quality of life and depression.
\end{abstract}

Methods: The research took place in the University Hospital Olomouc in 2017 and used questionnaires WHOQOL-BREF and BDI-II. 50 patients with psoriasis were chosen randomly. To process the data we used Mann-Whitney test (the level of significance $=5 \%$ ) and Spearman's correlation coefficient (the level of significance $=1 \%$ ).

Results: The results proved that psoriasis has a significant impact on quality of life. The scores for the ove- rall life quality as well as for individual domains were significantly lower in psoriatic patients than in the control group $(p<0.001)$. The degree of depression in patients with psoriasis showed statistically significant correlation in all domains of the quality of life. We proved negative correlation in the overall quality of life $\left(r_{s}\right.$ $\left.=-0.691^{* *}\right)$, physical condition $\left(r_{\mathrm{s}}=-0.499^{* *}\right)$, social relations $\left(r_{s}=-0.546^{* *}\right)$, overall health $\left(r_{s}=-0.396^{* *}\right)$, and environment $\left(r_{s}=-0.386^{* *}\right)$.

Conclusion: With regard to the ascertained negative correlation between psoriasis and depression and lower quality of life of the sufferers compared to the healthy population, it is essential for healthcare professionals to pay attention not only to somatic manifestations of the disease but also to the patients' mental health.

Keywords: psoriasis, depression, quality of life, nursing care, WHOQOL-BREF, BDI-II

Article received: 23.4.2019.

Article accepted: 1.7.2019.

DOI: $10.24141 / 1 / 5 / 2 / 4$

Corresponding author:

Jiří Vévoda

E-mail: jiri.vevoda@upol.cz 


\section{Introduction}

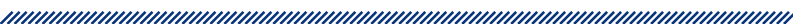

Psoriasis is a chronic skin disease characterized by scaly patches found anywhere on the body. It is an auto-immune genetically mediated inflammatory skin disease affecting approximately $2-5 \%$ of the world population. Men and women are affected equally $(1,2,3)$. In individual parts of the world the prevalence is different, a higher prevalence is found in developed countries (4.6\% of the population), e.g. in the USA psoriasis is the most frequent auto-immune disease with the prevalence of $0.9 \%$ (4). The disease may develop in any age, however, the onset is most frequent in people under 40 (3). The disease significantly affects everyday life of the patients and restricts them in many areas of their life. The problems are usually associated with physical appearance which leads to stigmatization. This affects the patient's psyche and may result in depression (5). Psychological problems associated with the disease affect a sufferer's quality of life more substantially than the skin disease and its manifestations (6).

\section{Quality of life of psoriasis sufferers}

Quality of life is a multidimensional concept that is difficult to precisely define due to its complexity. It involves both objective and subjective evaluation of different areas of life related especially to health and mental state as well as social interactions (7). Healthcare professionals usually focus on the visible manifestations of the disease. However, a complex approach resulting in the better quality of sufferers' life is necessary (8).

Due to frequent manifestations in the visible places psoriasis brings about a number of problems, such as low self-esteem, sexual dysfunction, anxiety and depression. Poor or very poor quality of life was found in $16.6 \%$ of patients with psoriasis (9). Dubertret et al. (12) carried out a European survey among 17900 patients with psoriasis: $77 \%$ of respondents considered psoriasis a fundamental life problem, $48 \%$ of respondents stated that the quality of their life is affected especially by a worsened physical appearance. The degree of quality of life reduction is also given by severity of the disease (2).

In the patients who are aware of which aspects of life are the most important for them the quality of life is better, they can cope with the disease to some extent (13).
The negative factor accompanying psoriasis is stigmatization $(1,14,15)$. Due to their aesthetic aspect skin diseases may be one of the main reasons for social rejection, which negatively affects personal and social life of sufferers (14). Psoriasis is the disease that significantly affects the way patients perceive themselves and the way they are perceived by others (1). Social rejection results in their sadness and bad mood (16). Due to visible manifestation of psoriasis the sufferers avoid swimming pools and hairdresser's or even public transport (15).

Psoriasis is also associated with higher incidence of obesity, smoking and alcohol abuse. This results in negatively affected quality of life and higher incidence of depression (17). Partnership and sexual problems represent another component part of quality of life (18). Patients with severe psoriasis are rather skeptical about finding a life partner (19).

\section{Depression in patients with psoriasis}

Everyday bad mood contributes to worsened symptoms of psoriasis and to poor quality of life as well as development of depression (20). Compulsive itching related to psoriasis affects the mental state of patients and depression incidence $(2,21)$. The incidence of depression in patients with psoriasis is rather variable and the prevalence is between $10-62 \%(11,25,22)$. In psoriatic patients depression develops 4-5 times more frequently than in healthy people, and the risk increases with severity of the disease $(9,23)$. Stigmatization, and isolation from healthy people, also contributes to depression (15). Suicidal ideation was found in almost $20 \%$ psoriasis sufferrers $(1,22)$. In the Netherlands as many as $50 \%$ of patients with psoriasis were referred by their dermatologists to psychological counselling and psychiatric treatment. However, only $8 \%$ out of them did undergo the recommended therapy. The other $50 \%$ of patients were not informed about the therapy by their attending physicians (24). $17.8 \%$ of these patients are on antidepressants (25). The negative impact of psoriasis on a patient's psyche is often more significant indicator of disability than the skin disease itself (26).

\section{Depression and quality of life}

One of the main consequences of depression is its negative impact on a patient's quality of life. Depression significantly worsens functions of an individual in such life areas as health condition or performance of social roles (27). Depression may even restrict functions in all do- 
mains of life quality (28). Depression is characterized by symptoms such as increased fatigue, loss of appetite, sadness, problems with sleeping, low energy or cognitive impairment. The symptoms significantly affect the patient's life. Ability to perform everyday routines is significantly impaired as well as abilities to fulfill family and work roles of the patient. Depression also leads to suicidal thoughts and behaviour (29). It has been proved that quality of life is significantly influenced by psychological aspects. Therefore, depression and other mental disorders should not be underestimated - on the contrary, they are significant predictors affecting quality of life (28). Poor quality of life, stigmatization and dissatisfaction with the treatment of psoriasis often result in insufficient patient cooperation and compliance, followed by inappropriate treatment procedures and lower treatment efficiency. This results in a patient's compromised well-being, and thus a vicious circle is formed (30). When the depression symptoms are reduced, manifestations of psoriasis reduce as well, and the patients' quality of life improves.

\section{Methods}

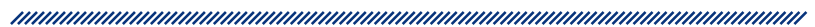

\section{Aims}

The aim of our survey was to determine the quality of life and the degree of depression in patients with psoriasis, and then to compare the rate of quality of life and depression between the research sample and the control group. Another aim was to establish the relationship between the degree of depression and the quality of life in patients with psoriasis.

\section{Research methods}

We chose the technique of quantitative research and used standardized questionnaires WHOQOL-BREF (the quality of life questionnaire WHO - its shortened version) (31) and BDI-II (Beck Self-Rating Depression Scale ) (32). The Czech version of WHOQOL-BREF is used for an individual's quality of life self-rating. It is a shortened version of the original WHOQOL-100 questionnaire that was prepared by a working group of experts who used data analyses from twenty world research centres. The shortened version was used to minimize time demands and burden put on the respondents (31).

WHOQOL-BREF includes 26 questions in which respondents subjectively assess quality of their life in the last two weeks. There are 24 items representing the sample of the best psychometric characteristics from WHOQOL-100 questionnaire that are subdivided into four domains: physical health, experiencing, social relations and environment, and two separated items assessing the overall quality of life and health condition. Mean gross scores of individual domains are calculated. The mean gross score for the first domain assessing physical health is based on seven questions: q3, q4, $\mathrm{q} 10, \mathrm{q} 15, \mathrm{q} 16, \mathrm{q} 17, \mathrm{q} 18$. The domain of experiencing is based on six questions: q5, q6, q7, q11, q19, q26. Social relations are specified by three questions: q20, q21 and q22. Environment is assesssed by eight items: q8, q9, q12, q13, q14, q23, q24 and q25. The questions on the overall quality of life $q 1$ and health condition $q 2$ are expressed separately by the mean score based on the five-point Likert scale 1-5, and the higher the number the better quality of life.

BD-II questionnaire is the latest version of Beck SelfRating Depression Scale from 1996 and it is used to detect symptoms of depression and their severity. The tool includes 21 items focused on affective, cognitive, motivational and physiological symptoms of depression. Respondents are asked to choose one of the four offered answers that is most consistent with their psychological condition over the last 30 days. The answers are scored on a 4-point scale from 0 to 3 points. The degree of depression is determined by the points added where the maximum sum total is 63 .

The test results are given with the help of the following cut off scores:

- 0-13 points - subtreshold depression

- 14-19 points - mild depression

- 20-28 points - moderate depression

- 29-63 points - severe depression (32).

\section{Organization of research of the basic set}

Our study is cross-sectional. The survey was carried out in the University Hospital Olomouc, the outpatient department of the Clinic of Dermatology and Venereology. The department works with the highest number of psoriasis sufferers in the Olomouc Region. Only outpatients took part in the survey. The data were collected with the method of simple intentional selection. The ques- 
tionnaires were distributed by the instructed nurses. Filled-in questionnaires were put into an enclosed envelope, sealed and returned into the prepared box.

\section{Characteristics of the research set}

The size of the se,t as well as the parameters monitored, were established according to the published studies $(11,15)$. The basic parameter was the question whether a respondent is being treated for psoriasis. Other parameters included:

- Sex (males and females)

- Age (18 years and over)

- Marital status (living alone, with a partner, with parents)

- The highest education completed (elementary, vocational, secondary, university)

- The length of treatment (in years)

The data were collected from June 2016 till January 2017. 60 questionnaires were distributed, 56 were returned (i.e. 93.3\%). 6 questionnaire sets were excluded due to incomplete filling in (i.e. 10\%). 50 questionnaire sets (83.3\%) were statistically processed.

\section{Ethics}

The research was approved by the Ethical Committee of the Faculty of Health Sciences, Palacky University, Olomouc.

\section{Statistics}

Data were statistically processed and analyzed with software IBM SPSS 19.0 and Excel (MS Office). ShapiroWilk test was used to determine the normality of data distribution. As the distribution was not normal, the non-parametric Mann-Whitney test (the level of significance $=5 \%$ ) was used to determine differences between the patients and control groups. To determine the relationship of depression scores and quality of life scores the Spearman correlation coefficient (the level of significance $=1 \%$ ) was used.

\section{Results}

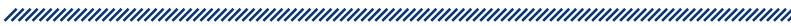

The patient group included 28 men and 22 women; the mean age $=43(S D=14.71$, the interval from 19 to 74 years); the mean length of disease manifestation = 19.62 (SD $=13.66$, the interval from 1 to 50 years). 11 patients lived alone, 32 with their partners, 7 with their parents. 4 respondents had elementary education, 32 completed vocational school, 21 completed secondary high school, 9 completed university education.

The control group included 33 men and 23 women; the mean age $=43.52(S D=14.67$, the interval from 19 to 73 years). 15 respondents lived alone, 36 with their partners, 5 with their parents. 3 respondents had elementary education, 18 completed vocational school, 23 completed secondary high education, 12 completed university studies.

The overall quality of life in the patient group was assessed with the questionnaire WHOQOL-BREF. Answers to the question „How would you assess the quality of your life?" are given in Table 1. No patient assessed the overall quality of their life as very poor.

To determine depression in the patients Beck Self-Rating Depression Scale for adults was used (BDI-II). The results are given in Table 2. Mild depression was found in $11(22 \%)$, moderate in $7(14 \%)$ and severe in $4(8 \%)$ psoriasis sufferers.

Mann-Whitney test was used for statistical comparison of the quality of life between the research group and the control group (see Table 3). The comparison revealed that there are statistically significant differences in the overall quality of life as well as in individual areas of life. The set of psoriasis sufferers had significantly lower overall quality of life, health condition, physical health, experiencing, social relationships and environment.

Mann-Whitney test was used for statistical comparison of depression between the patient group and the control group (see Table 4). The comparison proved a statistically significant difference between the groups $(p<0.001)$ - there was a significantly higher occurrence of depression in the psoriatic patients.

Spearman's correlation coefficient was used to determine the relationship between depression and quality of life in patients with psoriasis. What was found was a significantly negative correlation between the overall 


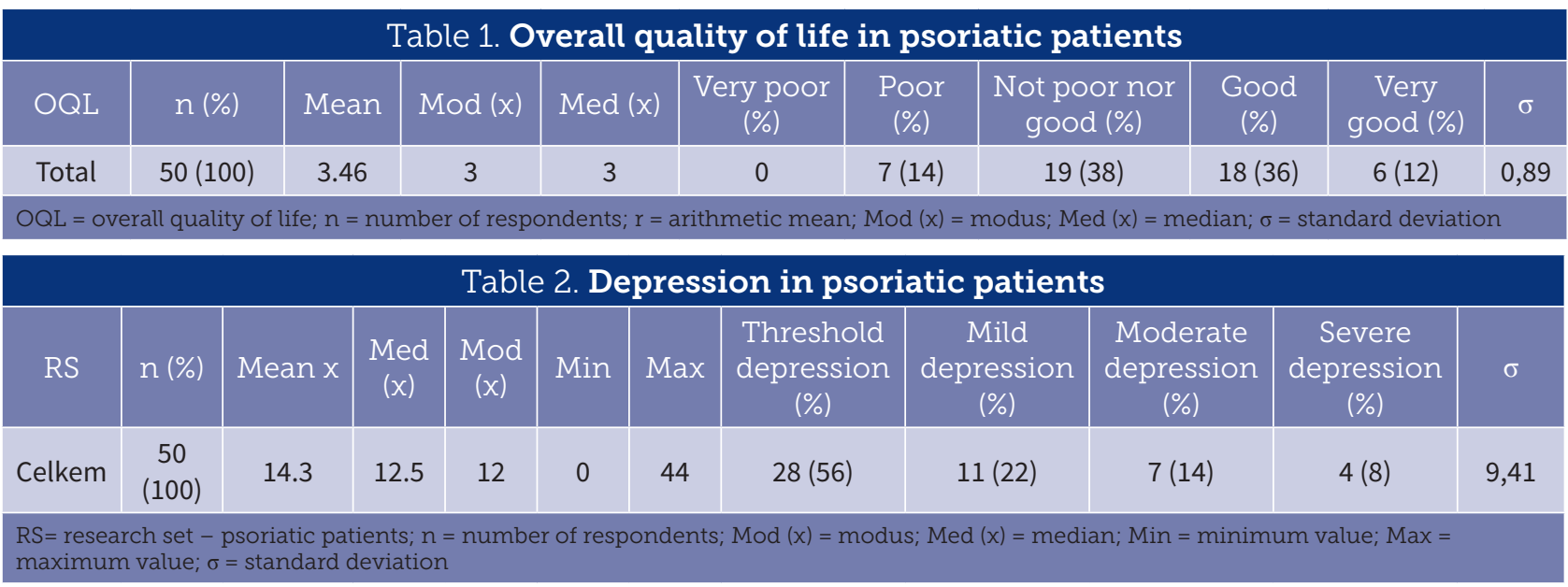

Table 3. Comparison of individual domains and overall quality of life of WHOQOL-BREF questionnaire (research set and control group)

\begin{tabular}{|c|c|c|c|c|c|c|c|c|c|}
\hline Domains & Set & $\mathrm{n}$ & $\begin{array}{l}\text { Mean } \\
(\mathrm{x})\end{array}$ & Min & $\operatorname{Max}$ & $\operatorname{Mod}(x)$ & $\operatorname{Med}(x)$ & $\sigma$ & $\mathrm{p}$ value \\
\hline \multirow{2}{*}{$\begin{array}{c}\text { Overall } \\
\text { quality of life }\end{array}$} & RS & 50 & 3,46 & 2 & 5 & 3 & 3 & ,885 & \multirow{2}{*}{0,000} \\
\hline & CG & 56 & 4,12 & 3 & 5 & 4 & 4 & ,623 & \\
\hline \multirow{2}{*}{$\begin{array}{l}\text { Physical } \\
\text { health }\end{array}$} & RS & 50 & 24,02 & 13 & 31 & 26 & 24,50 & 4,148 & \multirow{2}{*}{0,000} \\
\hline & CG & 56 & 29,29 & 21 & 35 & $28^{b}$ & 29,00 & 3,642 & \\
\hline \multirow{2}{*}{ Experiencing } & RS & 50 & 20,74 & 16 & 28 & 18 & 20,50 & 3,343 & \multirow{2}{*}{0,000} \\
\hline & CG & 56 & 24,88 & 17 & 29 & 27 & 25,00 & 2,861 & \\
\hline \multirow{2}{*}{$\begin{array}{l}\text { Social } \\
\text { relationships }\end{array}$} & RS & 50 & 10,82 & 5 & 15 & 11 & 11,00 & 2,106 & \multirow{2}{*}{0,000} \\
\hline & CG & 56 & 12,34 & 7 & 15 & 12 & 12,00 & 1,910 & \\
\hline \multirow{2}{*}{ Environment } & RS & 50 & 29,16 & 18 & 38 & 29 & 29,00 & 4,215 & \multirow{2}{*}{0,002} \\
\hline & CG & 56 & 31,70 & 7 & 15 & 33 & 32,50 & 3,474 & \\
\hline
\end{tabular}

Table 4. Comparison of the rate of depression between research set and control group

\begin{tabular}{c|c|c|c|c|c|c|c|c|c|}
\hline Depression & $n$ & Mean $(x)$ & Min & Max & Mod $(x)$ & Med $(x)$ & $\sigma$ & p value \\
\hline RS & 50 & 14.3 & 0 & 44 & 12 & 12.5 & 9.29 & 0,000 \\
\hline CG & 56 & 7.6 & 0 & 30 & 4 & 6 & 6.19 \\
\hline
\end{tabular}

RS = research set - psoriatic patients; CG = control group; $n=$ number of respondents; $\sigma=$ standard deviation; Mod $(x)=\operatorname{modus;~Med~}(x)=$ median; Min = minimum value; $M a x=$ maximum value

quality of life established with WHOQOL-BREF questionnaire and the rate of depression established with BDI-II $\left(r_{s}=-0.691^{* *}\right)$. The outcomes suggest a significant negative correlation between the rate of depression and experiencing domain $\left(r_{s}=-0.600^{* *}\right)$, a significant ne- gative correlation between the rate of depression and the domains of physical health $\left(r_{s}=-0.499^{* *}\right)$ and social relationships $\left(r_{s}=-0.546^{* *}\right)$, and a negative mean correlation between depression and the domains of health condition $\left(r_{s}=-0.396^{* *}\right)$ and environment $\left(r_{s}=-0.386^{* *}\right)$. 


\section{Discussion}

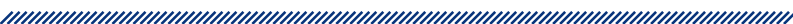

The presented work deals with the skin condition known as psoriasis and its potential impact on the quality of life and the rate of depression. The disease itself shows a significantly negative impact on the quality of life in almost $70 \%$ of psoriasis sufferers (10). Lakshmy et al. (9) used the same WHOQOL-BREF questionnaire and they found almost the same number of patients (35.6\%) who stated their quality of life was neither good nor bad ( $38 \%$ in our research). However, in our study there were twice as much patients (14\%) who considered their quality of life as poor or very poor (compared to $6 \%$ in the study by Lakshmy et al.(9)).

Another objective of our research was to establish the difference in the quality of life between the research group and the control group of respondents. The results proved significantly lower overall quality of life in patients with psoriasis which corresponds to the results given by Lee et al. (11). The resulting mean score of the overall quality of life in psoriasis sufferers was 3.46, i.e. the value below the level of the mean score of the population norm (3.82).

Psoriasis is usually accompanied by stigmatization. The patients are often excluded from their social environment which results in the increased incidence of depression and lower quality of their life $(14,15)$. Another aspect affecting the quality of life is the degree of satisfaction in partnership and sexual life. Problems occurring in an intimate relationship have a significantly negative impact on this domain of the quality of life $(15,33)$. In the domain "Social relationships" there is a statistically significant difference between the patient and the control group - the lower mean score in psoriasis sufferers shows the poorer quality of their life in the domain. A significantly negative correlation was found between this domain and the degree of depression $\left(r_{s}=-\right.$ $\left.0.546^{* *}\right)$ which suggests that the lower the quality of life the higher the rate of depression and vice versa. Mahmutovic et al. (34) found a similar negative correlation in this domain (rho $=-0.598^{* *} p=0.0001$ ). Therefore, the general public should be better informed about the disease in order to reduce stigmatization and improve the quality of life of the patients $(14,20)$.

A number of authors view quality of life as a complex condition that must be regarded from aspects of satisfaction in different domains, i.e. good physical and mental state, no illnesses, financial situation, interpersonal relationships, well-being, and a person's ability to achieve and follow their personal interests (35). The results show that there is a statistically significant difference between the patients and healthy people in the domain of experiencing. Psoriasis sufferers have a poorer quality of life in this domain. We also found a statistically significant negative correlation between this domain and the rate of depression. The poorer results in the domain "Experiencing", the higher the rate of depression and vice versa $\left(r_{s}=-0.600^{* *}\right)$. The same was also found in the domain of "Physical health" and the rate of depression $\left(r_{s}=-0.499^{* *}\right)$. Mahmutovic et al. (34) report a very strong negative correlation between "Physical health" and the rate of depression (rho=$0.793 p=0.0001$ ).

We also compared the rate of depression between the two groups (patient vs. control). The rate of depression was significantly higher in psoriasis sufferers which corresponds to the findings of Lee et al. (11). Psoriasis is often accompanied by depression and disturbed mental state is usually a higher indicator of morbidity rate than the skin disease itself (26). The worldwide depression prevalence is between 15 and $20 \%$ (36). The rate of depression in psoriatic patients is rather varied. Lakshma et al. (9) report depression in almost $79 \%$ of patients with psoriasis. However, some works state only $25-30 \%$ depression prevalence $(2,26)$. The rate of depression in our research sample was established with cut off scores of BDI-II questionnaire. Subthreshold depression manifestations were found in 28 respondents (56\%), mild depression in 11 respondents (22\%), moderate depression in $7(14 \%)$ and severe depression in 4 respondents ( $8 \%)$. Thus depression was recorded in $44 \%$ of our respondents. The resulting mean score was 14.3 points. The same results are reported by Jankowiak et al. (15).

Depression is the disease with a wide spectre of symptoms, such as fatigue, loss of appetite or sleep disorders. All the symptoms reduce the ability of an individual to lead a normal everyday life and may result in total exhaustion and failure (37). The treatment of psoriasis often deals with only skin problems and ignores disturbed psychological state of patients $(3,13)$. The mental state of the patients should be regularly monitored in order to note possible mental state changes early and treat them appropriately (3).

We also explored whether there exists the relationship between the rate of depression and quality of life in psoriatic patients. A strong correlation was found. This corresponds to the findings of similar studies that state 
that depression leads to worsened manifestations and longer treatment of psoriasis, and reduces quality of life of the patients $(15,28)$. Poor quality of life affects mental state of the patients resulting in depression a vicious circle is formed (30). Therefore, the patients should be provided with higher psychological support and understanding in order to improve their mental state and quality of life $(15,19)$. Improved quality of life of the patients serves as an indicator of good quality health care (7).

\section{Conclusion}

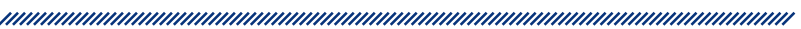

Psoriasis is more than just a somatic disease. Psoriastic patients have reduced quality of life and higher prevalence of depression. Higher incidence of depression may also be caused by psychological comorbidities, such as stigmatization and social exclusion. However, we cannot definitely prove that psoriasis leads to depression. Nevertheless, healthcare professionals should not focus solely on physical manifestations of the disease but also consider the psychological condition of their patients. A following research should identify psoriasis sufferers in which prevention is necessary to reduce the risk of depression.

\section{Study limits}

The research is not representative, it was carried out only on a regional scale, and thus the results cannot be generalized. The research did not deal with other factors that may impact the respondents' quality of life or rate of depression. These factors include, e.g. current life situation of a respondent, mood, pain, extent and intensity of the disease, or personality features.

\section{Aknowledgments}

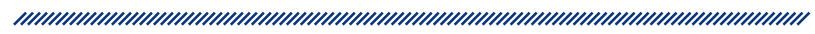

Supported by RVO: 61989592.

\section{References}

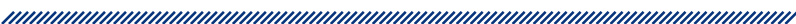

1. Bhosle MJ1, Kulkarni A, Feldman SR, Balkrishnan R. Quality of life in patients with psoriasis. Health Quality Life Outcomes. 2006;4:35.

2. Petraskiene R, Valiukeviciene $\mathrm{S}$, Blazevicienè A, Macijauskiene J. Competence in topic of psoriasis among nurses in healtcare institutions. Georgian medical news. 2015; 247(10):63-70.

3. Schmitt JM, Ford DE. Role of depression in quality of life for patients with psoriasis. Dermatology. 2007; 215(1):17-27.

4. Parisi R, Symmons DP, Griffiths CE, Ashcroft DM; Identification and Management of Psoriasis and Associated Comorbidity (IMPACT) project team.Global epidemiology of psoriasis: a systematic review of incidence and prevalence. Journal of Investigative Dermatology. 2013;133(2):377-8.

5. Darjani A, Heidarzadeh A, Golchai J, Sadr-Eshkevari S, Alizadeh N, Arami M et al. Quality of Life in Psoriatic Patients: A Study Using the Short Form - 36. International Journal of Preventive Medicine. 2014;5(9):1146-52.

6. Colombo D, Perego R. Quality of life in psoriasis. In: Lima H, editor. INTECH Open Access Publisher [online]: 2013. DOI: 10.5772/53998. Available from: https://www. intechopen.com/books/psoriasis-types-causes-andmedication/quality-of-life-in-psoriasis

7. Mareš, J., Marešová, J. Bolest a kvalita života u dětí. [PAIN AND QUALITY OF LIFE IN CHILDREN.] Bolest. 2004;7(4):214-17. Czech

8. Rakhesh Sv, D 'Souza M, Sahai A. Quality of life in psoriasis: A study from south India. Indian Journal of Dermatology, Venereology \& Leprology. 2008;74(6):600-6.

9. Lakshmy S, Balasundaram S, Sarkar S, Audhya M, Subramaniam E. A cross-sectional study of prevalence and implications of depression and anxiety in psoriasis. Indian journal of psychological medicine. 2015;37(4):434-40.

10. Barot PA, Brahmbhatt NY, Ninama HV, Kharadi DB, Malhotra SD. Quality of life in patient with psoriasis at a tertiary care hospital - A cross sectional study. National Journal of Medical Research. 2015;5(2):93-7.

11. Lee YW, Park EJ, Kwon IH, Kim KH, Kim KJ. Impact of psoriasis on quality of life: Relationship between clinical response to therapy and change in health-related quality of life. Annals of dermatology. 2010;22(4):389-96.

12. Dubertret L. Mrowietz U, Ranki A, van de Kerkhof PC, Chimenti S, Lotti T, Schäfer G. European patient perspectives on the impact of psoriasis: the EUROPSO patient membership survey. British Journal of Dermatology. 2006;155(4):729-36.

13. Khazanov GK, Ruscio AM. Is low positive emotionality a specific risk factor for depression? A meta-analysis of longitudinal studies. Psychological Bulletin. 2016; 142(9):991-1015. 
14. Hrehorów E, Salomon J, Matusiak L, Reich A, Szepietowski JC. Patients with psoriasis feel stigmatized. Acta dermato-venereologica. 2012;92(1):67-72.

15. Jankowiak B, Sekmistrz S, Kowalewska B, Niczyporuk W, Krajewska-Kułak E. Satisfaction with life in a group of psoriasis patients. Postep Derm Alergol. 2013;30(2):85-90.

16. Janoska P, Pawlak A, Kubiak I. Selected psychological aspects of psoriasis: case study analysis. Archives of Psychiatry and Psychotherapy. 2016;18(2):59-66.

17. Reich A, Welz-Kubiak K, Rams L. Apprehension of the disease by patients suffering from psoriasis. Postep Derm Alergol. 2014;31(5):289-93.

18. Ruiz-Villaverde R, Sánchez-Cano D, Rodrigo JR, Gutierrez CV. Pilot study of sexual dysfunction in patients with psoriasis: influence of biologic therapy. Indian journal of dermatology. 2011;56(6):694-9.

19. Daus L. Give them a hand: patients with hand and foot psoriasis require special attention. Dermatology Nursing 2008;20(4):291-3.

20. Makara - Studzińska M. Partyka I, Ziemecki P, Ziemecka $A$. The occurrence of emotional problems in somatic diseases based on psychodermatology. Archives of Psychiatry and Psychotherapy. 2014;16(2):23-8.

21. Remröd Ch., Sjöström K., Svensson A. Pruritus in psoriasis: a study of personality traits, depression and anxiety. Acta dermato-venereologica. 2015;95(4):439-44.

22. Hayes J, Koo J. Psoriasis: depression, anxiety, smoking, and drinking habits. Dermatologic therapy. 2010;23(2):174-80.

23. Strohal R, Kirby B, Puig L. Psoriasis beyond the skin: an expert group consensus on the management of psoriatic arthritis and common co-morbidities in patients with moderate-to-severe psoriasis. Journal of the European Academy of Dermatology and Venereology. 2014;28(12):1661-9.

24. Evers AW, Crijns MB, Kemperman PM. A peek inside the field of psychodermatology. Nederlands tijdschrift voor geneeskunde. 2012;157(12):56-9.

25. Dowlatshahi EA, Wakkee M, Herings RM, Hollestein LM, Nijsten T. Increased antidepressant drug exposure in psoriasis patients: a longitudinal population-based cohort study. Acta dermato-venereologica. 2013;93(5):544-50.
26. Elgendi A, Nada H, Mosbeh AS, Maatouk M, Abulghany M, Gulliver W. Depression Over Psoriasis: Assessment of associated Relief by addition of ADalimumab for the treatment of Psoriasis: Observational study. Journal of Dermatology \& Dermatologic Surgery. 2015;19(1):15-20.

27. Sivertsen H, Bjørkløf GH, Engedal K, Selbæk G, Helvik AS. Depression and Quality of Life in Older Persons: A Review. Dement Geriatr Cogn Disord. 2015;40(5-6):311-39.

28. Soponaru, C., Muraru, D., lorga, M. Meaning in life and sources of mening, depression and quality of life in patiens on hemodialysis. Philosophia. 2016;61(3):59-67.

29. Brenes GA. Anxiety, depression, and quality of life in primary care patients. Primary care companion to the Journal of clinical psychiatry. 2007;9(6):437-43.

30. Owczarek K, Jaworski M. Quality of life and severity of skin changes in the dynamics of psoriasis. Postepy dermatologii i alergologii. 2016;33(2):102-8.

31. Dragomirecká E. Česká verze dotazníku kvality života WHOQOL - překlad položek a konstrukce škál. Psychiatrie. 2006;10(2):1-6. Czech.

32. Beck AT, Steer RA, Brown GK. Manual for the Beck Depression Inventory-II. San Antonio, TX: Psychological Corporation; 1996.

33. Sharma S, Bassi R, Singh A. A comparative study of depression and anxiety in psoriasis and other chronic skin diseases. J Pakistan Assoc Dermatologists. 2011;21(4):235-40.

34. Mahmutovic J, Zukic M, Pasalic A, Brankovic S, Jaganjac A, Katana B. Correlation Between Quality of Life and Depression Among Persons Suffering from Psoriasis. Med Arch. 2017;71(5):341-46.

35. Heřmanová E. Kvalita života a její modely v současném sociálním výzkumu. Sociológia-Slovak Sociological Review. 2012;44(4):407-25. Czech.

36. Reddy EA, Srijampana AA, Rajana B, Muddana SS. Perceived stress and prevalence of depression among firstyear medical students. Journal of Dr. NTR University of Health Sciences. 2015;4(4):209-13.

37. Brenes GA. Anxiety, depression, and quality of life in primary care patients. Prim Care Companion J Clin Psychiatry. 2007;9(6): 437-43. 


\section{PSORIJAZA - UTJECAJ NA MENTALNO STANJE I KVALITETU ŽIVOTA POJEDINCA}

1 Šárka Vévodová

2 Filip Havelka

1 Jiří Vévoda

1 Bronislava Grygová

1 Ústav společenských a humanitních věd, Fakulta zdravotnických věd, Univerzita Palackého v Olomouci, Česká republika

2 Fakultní nemocnice Olomouc, Česká republika

\section{Sažetak}

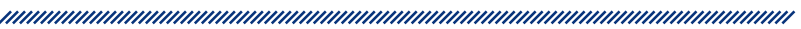

Uvod: Psorijaza od koje boluje otprilike 2-5\% stanovništva, je kronična kožna bolest koju karakteriziraju ljuskasti plakovi. Bolest ima negativan utjecaj na kvalitetu života, pa stoga osobe koje boluju od psorijaze često razviju depresiju. Naš rad bavi se kvalitetom života i depresijom kod oboljelih od psorijaze te se nastoji utvrditi povezanost između kvalitete života i depresije.

Metode: Istraživanje je provedeno u Sveučilišnoj bolnici u Olomoucu 2017. godine i korišteni su upitnici WHOQOLBREF i BDI-II. 50 bolesnika s psorijazom odabrano je metodom slučajnog odabira. Za obradu podataka korišten je Mann-Whitneyev test (razina značajnosti $=5 \%$ ) i Spearmanov koeficijent korelacije (razina značajnosti $=1 \%$ ).

Rezultati: Rezultati su pokazali da psorijaza ima značajan utjecaj na kvalitetu života. Rezultati za ukupnu kvalitetu života kao i za pojedinačne domene bili su značajno niži u bolesnika s psorijazom nego u kontrolnoj skupini ( $p$

$<0,001)$. Stupanj depresije u bolesnika s psorijazom pokazao je statistički značajnu korelaciju u svim područjima kvalitete života. Dokazana je negativna korelacija u ukupnoj kvaliteti života ( $\mathrm{rs}=-0.691^{* \star}$ ), fizičkom stanju $\left(r s=-0.499^{* \star}\right)$, društvenim odnosima $\left(r s=-0.546^{\star \star}\right)$, ukupnom zdravlju $\left(r s=-0.396^{* \star}\right)$ ) i okruženju $\left(r s=-0.386^{* \star}\right)$.

Zaključak: S obzirom na utvrđenu negativnu korelaciju između psorijaze i depresije i niže kvalitete života oboljelih u odnosu na zdravu populaciju, neophodno je da zdravstveni djelatnici obrate pozornost ne samo na somatske manifestacije bolesti, nego i na mentalno zdravlje pacijenata.

Ključne riječi: psorijaza, depresija, kvaliteta života, zdravstvena njega, WHOQOL-BREF, BDI-II 